\title{
ENDOTHELINS AND SARAFOTOXINS: PEPTIDES OF SIMILAR STRUCTURE AND DIFFERENT FUNCTION
}

\author{
Jiři Patočka ${ }^{1,2}$, Vladimír Měrka ${ }^{1}$, Vratislav Hrdina ${ }^{3}$, Radomír Hrdina ${ }^{3}$
}

Purkyně Military Medical Academy, Hradec Králové, Czech republic: Department of Toxicology ${ }^{1}$; University of South Bohemia, České Budějovice, Czech Republic: Department Radiology and Toxicology²; Charles University in Prague, Faculty of Pharmacy in Hradec Králové: Department of Pharmacology and Toxicology ${ }^{3}$

Summary: Endothelins are endogenous vasoactive peptides that are considered among the most potent vasoconstrictor substances known. In addition to their vascular effects, endothelins and their receptors have been shown to be present in many organs and share plenty physiological and pathophysiological functions. Sarafotoxins are natural substances from the venom of snakes genus Atractaspis, structurally and pharmacologically near to endothelins. The current minireview focuses on the chemical and molecular aspects of endothelins and sarafotoxins, and their receptors in physiological and pathophysiological processes.

Key words: Endothelin; Sarafotoxin; Endothelin receptor; Biosynthesis; Physiology; Pathophysiology; Atractaspis engaddensis

\section{Introduction}

As early as 1985 , a peptidergic activity produced in endothelial cells that caused coronary vasoconstriction was described and the family of peptides named endothelins has been subsequently isolated and identified by Yanagisawa et al. (62). It was first isolated, characterized, and cloned in porcine aortic endothelial cells. These peptides figure local hormones with diverse tasks in health and disease (25). Later a group of snake cardiotoxic venoms from Israel mole viper Atractaspis engaddensis Haas, was isolated and characterized by Kochva et al. (34). Presently high level of homology between snake venom sarafotoxins and mammalian endothelins was described $(5,33)$. These native peptides from different sources come under endothelin/sarafotoxin family of biologically active compounds (6). These are peptides of similar structure but different origin and function: first are important regulation molecules in all vertebrate organisms, second are toxic principles of venom from dangerous snake Israel mole viper.

\section{Structure of endothelins and sarafotoxins}

The endothelins are a family of related peptides. Each has 21 aminoacids. Each isoform has two intra-chain disulphide bridges linking paired aminoacid residua producing an unusual semiconical structure. These bridges and C-terminal domain appear to be essential for the actions of endothelins as their removal leads to substantial loss of biological activi- ty (47). Also all known sarafotoxins are 21 amino acids peptides with two intra-chain disulphide bridges. The similarity of endothelins and sarafotoxins is evident from Fig. 1.

$$
\begin{aligned}
& \text { Endothelin-1 } \\
& \text { Endothelin-2 } \\
& \text { Endothelin-3 } \\
& \text { VIC } \\
& \text { SFTX S6a } \\
& \text { SFTX S6b } \\
& \text { SFTX S6c }
\end{aligned}
$$

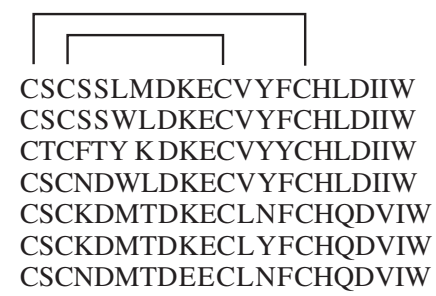

Fig. 1: Primary structure of endothelins, vasoactive intestinal contractor (VIC), and sarafotoxins (SFTX). All peptides have 21 amino acids and two disulphide bridges between $\mathrm{Cys}^{1}$ - $\mathrm{Cys}^{15}$ and between $\mathrm{Cys}^{3}-\mathrm{Cys}^{11}$. Amino acids are marked with one letter codes: $\mathrm{C}=$ Cysteine, $\mathrm{D}=$ Aspartic acid, $\mathrm{E}=$ Glutamic acid, $\mathrm{F}=$ Phenylalanine, $\mathrm{H}=$ Histidine, $\mathrm{I}=$ Isoleucine, $\mathrm{K}=$ Lysine, $\mathrm{L}=$ Leucine, $\mathrm{M}=$ Methionine, $\mathrm{N}=$ Asparagine, $\mathrm{Q}=$ Glutamine, $\mathrm{S}=$ Serine, $\mathrm{T}=$ Threonine, $\mathrm{V}=$ Valine, $\mathrm{W}=$ Tryptophan, $\mathrm{Y}=$ Tyrosine.

\section{Types of endothelins}

The endotheline family consists of 3 structurally similar isopeptides: endothelins-1, -2 , and -3 . Although vascular endothelial cells are the major source of endothelins, there are also produced by a wide variety of cell types including renal tubular endothelium, glomerular mesangium, cardiac 
myocytes, glia, the pituitary, macrophages, mast cells, etc. (28). The genes that encode these peptides are found to be on chromosomes 6, 1 and 20 respectively (28). Endothelin-1 is a peptide secreted mostly by vascular endothelial cells, the predominant isoform expressed in vasculature and the most potent vasoconstrictor currently known (1). Endothelin-2 has similar vasoconstrictor potency to endothelin-1 and appears to be synthesized predominantly in the kidney and intestine (26). Endothelin-3 is the least potent vasoconstrictor. Its precursor mRNA is detectable in the central nervous system, kidneys, lungs, pancreas and spleen (18).

\section{Biosynthesis of endothelins}

Endothelin-1 is derived from the parent protein molecule, pre-proendothelin consisting of 212 amino acids. Preproendothelin is primarily processed in the cytosol of the endothelial cells to proendothelin 1 of 38 or 39 amino acids depending on the species (28). The production of endothelin 1 from proendothelin-1 occurs by enzymatic cleavage by the action of cell membrane enzyme - endothelin-converting enzyme (ECE). It is suggested that the ECE is pivotal in the genesis of endothelin-1 (13). Peptide backbone is splitting at the $\operatorname{Trp}^{21-} \mathrm{Val}^{22}$ site (28). Endothelin-1 is also produced by epithelial, mesangial, neuronal glial cells and liver (15).

Secretion of endothelin-1 is stimulated by a variety of substances. These include the catecholamines, proteins such as thrombin, angiotensin-2 and arginine vasopressin (AVP), high and low density lipoproteins, transforming growth factor B, insulin, several cytokines and ions (calcium). Various vasoactive substances like nitric oxide, atrial natriuretic peptide, $\mathrm{PGI}_{2}$ and $\mathrm{PGE}_{2}$ inhibit the production and secretion of endothelin-1. Also hypoxia and ischemia are important physiological stimuli for endothelin-1 production (36). Plasma concentrations of endothelin- 1 has been reported to vary between 0.25 and 20 pg. $\mathrm{ml}^{-1}$ (58).

Endothelin-2 is produced primarily in the kidney and intestine from undetermined cells. It is also produced in the placenta, uterus and myocardium. Endothelin-2 has no unique function known to date and it has not been demonstrated in plasma. Endothelin-3 has been found in high concentrations in the brain (46).

\section{The source of sarafotoxins}

Sarafotoxins are natural substances from the venom of snakes genus Atractaspis. This genus represent the evolutionary old sort of reptiles and includes about 18 species of small, fossorial African and Middle Eastern snakes (54) known for their ability to envenomate prey with a backwards stab of a single fang $(10,21)$. Their curious envenomation behavior is associated with unusual features of cephalic anatomy (57), including a viper-like maxilla, a palatopterygoid bar with a gap between the pterygoid and the palatine, as well as few teeth on the palatine and none on the pterygoid.
The toxicologically best known species of genus Atractaspis is A. engaddensis (21) known as Israel mole viper or erdviper. Israel mole viper is a very dangerous snake. In Middle East this reptile is on the list of ten most dangerous snakes and its snakebite is life threatening (35). A bite by Israel mole viper can sometimes produce a considerable oedema, paresthesia, blisters and local necrosis. A specific antiserum is available in endangered regions (27).

Israelite research workers (37) write that during routine milking of a group of Atractaspis engaddensis, one of them was bitten in the index finger by one fang, as is characteristic of bites by snakes of this genus. Local effects, oedema, erythema and numbness appeared within minutes, followed by systemic effects, including general weakness, sweating, pallor, fluctuations in the level of consciousness, vomiting and watery non-bloody diarrhoea. Gross oedema of the hand developed and extended up to the forearm. Two hours after admission to the hospital, blood pressure rose to $180 / 110$ $\mathrm{mm} \mathrm{Hg}$, the ECG showed normal sinus rhythm and no signs of atrioventricular conduction block. An ECG obtained $24 \mathrm{~h}$ after the bite showed new T-wave inversions in leads $\mathrm{V} 5+6$, which gradually returned to baseline within several days. The local effects healed during the following weeks, but some discoloration and tenderness remained even 10 months after the bite. A maximal exercise (SPECT) study carried out five months after the bite was normal and a multigated radionuclear ventriculogram (MUGA) showed normal left-ventricular function. It may be assumed that the rise in blood pressure observed in this case reflects a systemic vasoconstrictive effect of the sarafotoxins, while the ST changes may have been caused by the direct effect of the toxins on the heart or indirectly by vasoconstriction of the coronary arteries. However, ischaemia secondary to a rise in blood pressure or to excitement could also explain the observed ECG-changes.

According to „Australian venom and toxin databasis“ the toxicity of venom from A. engaddensis is comparable to the venoms from the other dangerous snakes such as Acanthophis antarcticus (common death adder), Dendroaspis polylepis (black mamba), Crotalus durissus terrificus (cascabel) (4).

\section{Types of sarafotoxins}

Sarafotoxins are snake cardiotoxic peptides from the venom of $A$. engaddensis, structurally related to the endothelins $(14,23,27,33)$. The venom from the snake $A$. engaddensis has a very high lethal potency, with an i.v. LD $_{50}$ of 0.06-0.075 mg. $\mathrm{kg}^{-1}$ body weight in mice. The action of the venom is rapid and death results from seemingly neurotoxic effects. However, even at high concentrations, the venom does not block contractions of skeletal muscles that are directly or indirectly stimulated. The most prominent action of the venom is seen in the function of the heart in anesthetized mice, with or without artificial respiration. The ECG changes are similar to those recorded in human 
victims and are the result of an A-V block that is caused by an apparent direct action of the venom on the heart (60). In experiments in mice the venom $(0.1 \mathrm{mg} / \mathrm{kg}$, i.v. $)$ produced a transient hypertension followed by fluctuation of arterial blood pressure, leading to cardiac failure within $20 \mathrm{~min}$. Various kinds of ECG changes, including S-T depression and $\mathrm{A}-\mathrm{V}$ block were observed within $10 \mathrm{sec}$ after injection. A dose as low as 1 microgram of venom injected into the perfusion system produced a marked coronary vasospasm in the Langendorff heart preparation, whereas no deleterious effect was found in the atrial preparation at a concentration as high as 10 micrograms/ml. It is concluded that the cardiotoxic effects of the venom are primarily due to coronary vasospasm (39). The cardiotoxic polypeptides isolated from the venom of the snake $A$. engaddensis has an $\mathrm{LD}_{50}$ of 15 micrograms. $\mathrm{kg}^{-1}$ body weight in white mice. Intravenous administration in mice of lethal doses of the toxin causes death, within seconds (61).

Three isotoxins, named sarafotoxins S6a, S6b and S6c, with strong cardiotoxic activity were isolated from the venom of $A$. engaddensis by Takasaki et al. (55). All three sarafotoxins are homologous consisting of 21 amino acid residues. Later also other very similar natural cardiotoxin from the venom of $A$. engaddensis was isolated and described: sarafotoxin d (S6d). S6d differs from S6b in two substitutions: Ile $^{19}$ instead of Val and $\mathrm{Thr}^{2}$ instead of Ser. The toxicity of S6d and its vasoconstriction potency are very low in comparison to $\mathrm{S} 6 \mathrm{a}$ and $\mathrm{S} 6 \mathrm{~b}$, whereas its $\mathrm{IC}_{50}$ for ${ }^{125} \mathrm{I}-\mathrm{S} 6 \mathrm{~b}$ binding is similar to that of S6b. It is suggested that Thr to Ser substitution, which is shared by two additional weak members of the endothelin/sarafotoxin family, S6c and endothelin-3, affects the biological activity of S6d as well $(5,6)$.

\section{Vasoactive intestinal contractor}

Vasoactive intestinal contractor (VIC) is a member of the peptide endothelin family.

This peptide, three amino acids different from endothelin-1, has less activity in increase of intracellular calciumion level and in percent of response cells than endothelin-1, endothelin-2, and VIC-S4L6 (one amino acid different from endothelin-1). $\mathrm{EC}_{50}$ of endothelin-1, VIC-S4L6, endothelin-2, and VIC were $0.5 \mathrm{nM}, 0.6 \mathrm{nM}, 2.0 \mathrm{nM}$, and 20 $\mathrm{nM}$, respectively. VIC-like peptide (VIC-LP), 16 amino acids fragment of VIC precursor protein, had no effect with a single administration of up to 10 micromol. $^{-1}$ (30). From the Masuo et al. (41) results it is suggesed that VIC and endothelin-2 may have certain physiological roles that differ from those of endothelin-1 in the brain and pituitary gland.

\section{Endothelin/sarafotoxin receptors}

Endothelin receptors are widely expressed in all tissues, which is consistent with the physiological role of endothelins as ubiquitous endothelium-derived vasoactive peptides, contributing to the maintenance of vascular tone.
Three high affinity endothelin receptors (ETs) belonging to the $G$ protein coupled family have been identified in human tissues: endothelin $\mathrm{A}$ receptor $\left(\mathrm{ET}_{\mathrm{A}}\right)$, endothelin $\mathrm{B}$ receptor $\left(E_{B}\right)$ and endothelin $\mathrm{C}$ receptor $\left(\mathrm{ET}_{\mathrm{C}}\right)$. ETs are upregulated by ischaemia and cycloserine while angiotensin, phorbol esters and endothelin-1 itself lead to downregulation. $\mathrm{ET}_{\mathrm{A}}$ receptor is present mainly in the vascular smooth muscle and cardiac muscle and mediates vasoconstriction (42). These receptors have ten fold greater affinity for endothelin-1 or endothelin-2 than endothelin-3. $\mathrm{ET}_{\mathrm{B}}$ is expressed predominantly on endothelial cells and extensively throughout the kidney, liver and uterus (8). This receptor is also the most abundant endothelin-binding protein in the brain and is found mainly on astrocytes (49). $\mathrm{ET}_{\mathrm{B}}$ receptor binds to all form of endothelins with comparable affinity (2). $\mathrm{ET}_{\mathrm{C}}$ has been isolated as last from the frog melanophores. This receptor binds endothelin-3 with 3-4 fold greater affinity than endothelin-1. This receptor may also be present on endothelial cells (31).

\section{Mechanism of endothelin action}

After binding to receptors, endothelin-l activates phospholipase $C$ via a pertussis toxin-insensitive $G$ protein (56). This causes a rapid increase in intracellular concentration of inositol triphosphate, which releases $\mathrm{Ca}^{2+}$ from intracellular stores. It also increases membrane diacylglycerol, thus activating protein kinase $2 \mathrm{C}$. The signaling mechanisms vary between $\mathrm{ET}_{\mathrm{A}}$ and $\mathrm{ET}_{\mathrm{B}}$ receptors. $\mathrm{ET}_{\mathrm{A}}$ receptor is coupled to phospholipase and intracellular calcium mobilization and leads to stimulation of cAMP production in some but not all cells, while $\mathrm{ET}_{\mathrm{B}}$ receptor controls sodium/hydrogen exchange independently of protein kinase $\mathrm{C}$ and inhibits agonist induced cAMP (3). The signaling mechanism of $\mathrm{ET}_{\mathrm{C}}$ is presently unknown (16).

\section{Physiology and pathophysiology of endothelins}

The endothelin family of peptides are very potent endogenous vasoconstrictor and pressor agents, secreted by various cells and tissues in the human body. The endothelins have been the subject of intense research on their physiological function and potential pathophysiological role in various disease states. There is now good evidence that endothelins regulate vascular tone and blood pressure and are important in the regulation of various functions like pulmonary, endocrine, central nervous system and foetal development. Studies with endothelin receptor antagonists have underlined the important role of endothelins in various disease states like chronic heart failure, hypertension, bronchial asthma, subarachnoid haemorrhage, vasospastic disorders and some developmental disorders.

\section{Vascular Effects}

Stimulation of $\mathrm{ET}_{\mathrm{A}}$ and $\mathrm{ET}_{\mathrm{B}}$ receptors on vascular smooth muscle cells results in sustained vasoconstriction. Stimu- 
lation of $\mathrm{ET}_{\mathrm{B}}$ receptors on vascular endothelial cells results in vasodilatation, probably via release of prostacyclin $\left(\mathrm{PGI}_{2}\right.$ and NO). Local ECE inhibition and selective $\mathrm{ET}_{\mathrm{A}}$ receptor blockade in the forearm vasculature of healthy volunteers substantially

Increase forearm blood flow suggesting that endogenous generation of endothelin-1 contributes to maintenance of basal vascular tone in healthy humans (24). In healthy human subjects, systemic administration of low doses of endothelin-1 produces a modest increase in blood pressure (59). Endothelin-1 also causes venoconstriction in humans. Endothelin-1 enhances the conversion of angiotensin-I to angiotensin-II in cultured cells and increases adrenal synthesis of both adrenaline and aldosterone. Furthermore angiotensin II and arginine vasopressin (AVP) increase endothelin-1 secretion from the cultured endothelial cells. Thus endothelial secretion of endothelin-l and renin-angiotensin-aldosterone activation may potentiate each other and synergistically augment vasoconstriction.

Endothelin-1 has dual vasoactive effects, mediating vasoconstriction via $\mathrm{ET}_{\mathrm{A}}$ receptor activation of vascular smooth muscle cells and vasorelaxation via $\mathrm{ET}_{\mathrm{B}}$ receptor activation of endothelial cells. Although it is commonly accepted that endothelin-1 binding to endothelial cell $\mathrm{ET}_{\mathrm{B}}$ receptors stimulates nitric oxide (NO) synthesis and subsequent smooth muscle relaxation, the signaling pathways downstream of $\mathrm{ET}_{\mathrm{B}}$ receptor activation are unknown (40).

The role of endothelins in the pathogenesis or maintenance of hypertension is controversial. In spontaneously hypertensive rats, antibodies to endothelin can normalize blood pressure and restore various associated renal dysfunction to normal. This occurs despite the fact that in spontaneously hypertensive rats the plasma levels of endothelin are not different from normotensive rats (51). Advances in the study of pathophysiological mechanisms and the relationship between several regulatory systems show that endothelins role is modified by more other peptides (50).

\section{Cardiovascular Effects}

Endothelin-1 has potent positive chronotropic and inotropic effects in vitro (29). At higher doses positive inotropism is opposed by ischaemia. In vivo, higher doses cause a decrease in cardiac output probably due to a combination of systemic vasoconstriction, increasing afterload and coronary vasoconstriction, causing myocardial ischaemia (20). In addition, endothelin-1 appears to play an important role during that perinatal and postnatal period. Endothelin-1 can dramatically increase resistance in the placental microcirculation and may be involved in blood flow redistribution with hypoxia. At birth, the increase in oxygen tension is important in triggering ductus vasoconstriction. It is proposed that oxygen triggers closure of the ductus arteriosus by activating a specific, cytochrome P450-linked reaction, which in turn stimulates the syn- thesis of endothelin-1. On the neonatal heart, endothelin-1 has a positive chronotropic but negative inotropic effect. In the newborn piglet and the fetal lamb, endothelin-1 causes a potent, long-lasting pulmonary vasoconstriction (45). Endothelin- 1 appears to be a causative agent in the pathogenesis of pulmonary hypertension (11).

\section{Central Nervous System Effects}

The endothelin system, consisting of three peptides, two peptidases and three G-protein coupled receptors, is widely expressed in the brain cell types and brain-derived tumor cell lines. The stimulation of endothelin receptors elicits a variety of short- and long-term changes at cellular level but the effects of the modulation of the endothelin system in brain physiology and pathophysiology are, at the present time, poorly understood. Altered expression of endothelins in reactive astrocytes has been observed in many pathological conditions of the human brain, such as infarcts, traumatic conditions, Alzheimer's disease and inflammatory diseases of the brain. In addition, recent studies have shown that endothelin antagonists might inhibit growth and induce cell death in human melanoma cells in vitro and in vivo, and have emphasized a possible role of endothelin peptides as autocrine or paracrine factor in the proliferation and dissemination of tumor cell lines (52).

\section{Renal Effects}

Endothelin-1 at plasma concentrations found in certain pathophysiological conditions in humans may influence renal perfusion and renal sodium and water excretion. Sorensen et al. (53) show that intravenous infusion of endothelin- 1 at a rate of 1 picomol. $\mathrm{min}^{-1} \cdot \mathrm{kg}^{-1}$ for $60 \mathrm{~min}(\mathrm{n}=9)$ or placebo $(n=9)$ was investigated in 18 healthy human volunteers with a mean age of $30 \mathrm{yr}$. In response to endothelin-1 infusion, concentration of endothelin-1 increased from $0.88 \pm 0.27$ to $10.73 \pm 4.79$ (SD). picomol..$^{-1}$. Diastolic blood pressure increased by $7.8 \%(\mathrm{P}<0.01)$ and heart rate decreased by $14.0 \%$ ( $\mathrm{P}<0.01)$, whereas systolic blood pressure did not change. Renal plasma flow decreased by $34.7 \%$, glomerular filtration rate decreased by $16.1 \%$, and renal vascular resistance increased by $66.0 \%$ ( $\mathrm{P}<0.01$ all). Urinary sodium excretion decreased by $57.9 \%$ and urinary flow rate by $40.2 \%$ ( $P<0.01$ for both). As judged from the clearance of lithium, endothelin-1 did not change absolute reabsorption of sodium and water in the proximal tubules, but in the distal tubules absolute reabsorption of both sodium and water decreased significantly. Plasma concentrations of angiotensin II, aldosterone, AVP, and atrial natriuretic peptide did not change in response to endothelin-1 infusion.

Recent data suggest that the renal effect of cyclosporine A, a widely used immunosuppressive agent, causes renal vasoconstriction and systemic hypertension that are possibly mediated by endothelin (9). Endothelin may be a mediator in the pathogenesis of acute renal failure (19). 


\section{Pulmonary Effects}

Endothelin-1 is a potent activator of nonselective cation currents in bronchial smooth muscle cells (43). Endothelin-1 is a potent mitogen regulator of smooth muscle tone, and inflammatory mediator that may play a key role in diseases of the airways, pulmonary circulation, and inflammatory lung diseases, both acute and chronic (17). Endothelin-1 is one of more neuropeptides that share in vascular resistance in the mammalian pulmonary circulation (32) and possible mediator in some respiratory diseases (22).

\section{Endocrine Effects}

Endothelins synthesized within the adrenal cortex may act as factors to regulate adrenocortical cell activity. The expression of endothelins has been detected in normal, hyperplastic and neoplastic adrenocortical cells. The occurrence of endothelin receptors has been described in the different zones of the cortex. Endothelins stimulate the secretion of both glucocorticoids and mineralocorticoids, and modulate the proliferation of adrenocortical cells. The effects of endothelins on steroidogenic cells are mediated through the activation of various signaling mechanisms including stimulation of phospholipase $\mathrm{C}$, phospholipase $\mathrm{A}_{2}$ and adenylyl cyclase activity, as well as calcium influx through plasma channels. These observations suggest that locally produced endothelins may play an important role in the regulation of corticosteroid secretion and in the control of mitogenesis in normal and tumoral adrenocortical cells (12). Endothelin-1 is overtly increased in severe congestive heart failure (CHF) and thus is a likely candidate for the aldosterone 'escape' phenomenon in CHF. Endothelin-1 is expressed in the adrenal cortex, together with its receptors $\mathrm{ET}_{\mathrm{A}}$ and $\mathrm{ET}_{\mathrm{B}}$, and directly stimulates aldosterone secretion in different species, in humans by acting via both $\mathrm{ET}_{\mathrm{A}}$ and $\mathrm{ET}_{\mathrm{B}}$ receptor subtypes (48). Endothelins also participate in the regulation of pituitary function (38) and probably in further endocrine effects.

\section{Endothelins and sarafotoxins as chemical weapons}

Recently the group of regulatory peptides is considered as agents exploitable for terrorism or warfare purposes (7, 44). Endothelins as physiologically very active bioregulators and sarafotoxins as natural biotoxins act as dangerous compounds and may be misused for these undesirable activity.

\section{Endothelin receptor agonists and antagonists}

Compounds with affinity to endothelin receptors represent a novel interesting group of natural and/or synthetically prepared substances with significant physiological effects and thay can become a wide potential of new therapeutics in human and veterinary medicine. Some of these agents are currently being assessed in early phase of clinical trials (42). It is still not clear which of these will prove to be of most therapeutic value. However, evaluation of this undoubtedly interesting compounds is beyond the scope of our minireview.

\section{References}

1. Agapitov AV, Haynes WG. Role of endothelin in cardiovascular disease. J Renin Angiotensin Aldosterone Syst 2002;3:1-15.

2. Arai $\mathrm{H}$, Hori S, Aramori I. Cloning and expression of a cDNA encoding an endothelin receptor. Nature 1990;348:730-3.

3. Aramori I, Nakanishi S. Coupling of two endothelin receptor subtypes of differing signal transduction in transfected Chinese hamster ovary cells. J Biol Chem 1992;267:12468-74

4. Australian venom and toxin databasis. http://mzone.mweb.co.za/residents/net12980/ld50tot.html

5. Bdolah A, Wollberg Z, Ambar I, Kloog Y, Sokolovsky M, Kochva E. Disturbances in the cardiovascular system caused by endothelin and sarafotoxin. Biochem Pharmacol 1989;38:3145-6.

6. Bdolah A, Wollberg Z, Fleminger G, Kochva E. SRTX-d, a new native peptide of the endothelin/sarafotoxin family. FEBS Lett 1989;256:1-3.

7. Bokan S, Breen JG, Orehovec Z. An evaluation of bioregulators as terrorism and warfare agents. ASA Newsletter 2002;02-3:16-9.

8. Bousso-Mittler D, Kloog Y, Woilberg Z, Bdolah A, Kochva E, Sokolovsky M. Functional endothelin/sarafotoxin receptors in the rat uterus. Biochem Biophys Res Commun 1989;162:952-7.

9. Cavarape A, Endlich K, Feletto F, Parekh N, Bartoli E, Steinhausen M. Contribution of endothelin receptors in renal microvessels in acute cyclosporine-mediated vasoconstriction in rats. Kidney Int 1998:53:963-9.

10. Corkill NL, Ionides CJP, Pitman CRS. Biting and poisoning by the mole vipers of the genus Atractaspis. Trans R Soc Tro Med Hyg 1959;53:95-101.

11. Crespo MC, Morales LV, Alonso RH, Alonso OB, Molero GR. Primary pulmonary hypertension and its management (Article in Spanish) Farm Hosp 2004;28:48-55.

12. Delarue C, Conlon JM, Remy-Jouet I, Fournier A, Vaudry H. Endothelins as local activators of adrenocortical cells. J Mol Endocrino 2004;32:1-7.

13. D’Orleans-Juste P, Plante M, Honore JC, Carrier E, Labonte J. Synthesis and degradation of endothelin-1. Can J Physiol Pharmacol. 2003;81:503-10.

14. Ducancel F. The sarafotoxins. Toxicon 2002; 40:1541-5.

15. Emori T, Hirata Y, Oha K. Cellular mechanisms of endothelin 1 production in cultured human endothelial cells. Hypertension 1991;18:304-15.

16. Endoh M, Fujita S, Yang HT, Talukder MA, Maruya J, Norota I. Endothelin: receptor subtypes, signal transduction, regulation of $\mathrm{Ca}^{2+}$ transients and contractility in rabbit ventricular myocardium. Life Sci 1998;62:1485-9.

17. Fagan KA, McMurtry IF, Rodman DM. Role of endothelin-1 in lung disease. Respir Res 2001;2:90-101.

18. Firth JD, Ratcliffe PJ. Organ distribution of the three rat endothelin messenge RNAs and the effects of ischemia on renal gene expression. J Clin Invest 1992;88: 1023-31.

19. Firth JD, Ratcliffe PJ, Raine AEG, Ledingham JG. Endothelin, an important factor in acute renal failure. Lancet 1988;2(8621):1179-82.

20. Geotz KL, Wang BC, Madwed JB. Cardio vascular, renal and endocrine responses to intravenous endothelin in conscious dogs. Am J Physiol 1988;255: R1064-8.

21. Golani I, Kochva E. Striking and other offensive and defensive behavior patterns in Atractaspis engaddensis (Ophidia, Atractspididae). Copeia 1988: 792-7.

22. Goldie RG, Fernandes LB. A possible mediator role for endothelin-1 in respiratory disease. Monaldi Arch Chest Dis 2000;55:162-7.

23. Graur D, Bdolah A, Wollberg Z, Kochva E. Homology between snake venom sarafotoxins and mammalian endothelins. Israel J Zool 1988/89;35:171-5.

24. Haynes WG, Webb DJ. Contribution of endogenous generation of endothelin-1 to basal vascular tone. Lancet 1994:344:852-4.

25. Haynes WG. Webb DJ. The endothelin family of peptides: local hormones with diverse tasks in health and disease. Clin Sci 1993;84:485-500.

26. Howard PG, Plumpton C, Davenport AP. Anatomical localisation and pharmacological activity of mature endothelins and their precursors in human vascular tissue. J Hypertens 1992;10:1379-86.

27. Hrdina V, Hrdina R, Jahodáŕ L, Martinec Z, Měrka V. Přírodní toxiny a jedy. Praha: Galén a Karolinum, 2004:302.

28. Inoue A, Yanagisawa M, Kimura S et al. The human endothelial family: three structurally and pharmacologically distinct isopeptides predicted by three separate genes. Proc Natl Acad Sci USA 1989;86:2863- 7

29. Ishikawa T, Yanagisawa M, Kimura S. Positive inotropic action of novel vasoconstrictor peptide endothelin on guinea pig atria. Am J Physiol 1988;255 H970-3. 
30. Iwashima A, Kobayashi M, Saida K et al. Contraction and intracellular calciumion elevation of cultured human aortic smooth muscle cells by endothelin-1, vasoactive intestinal contractor (VIC) and the derivatives. In Vitro Cell Dev Biol Anim 1997;33:751-6

31. Karne S, Jayawickreme CK, Lerner MR. Cloning and characterization of an endothelin-3 specific receptor (ETc receptor) from Xenopus laevis dermal melanophores. J Biol Chem 1993;268:126-33.

32. Keith IM.The role of endogenous lung neuropeptides in regulation of the pulmonary circulation. Physiol Res 2000;49:519-37.

33. Kloog Y, Sokolovsky M. Similarities in mode and sites of action of sarafotoxins and endothelins. Trends Pharmacol Sci 1989;10:212-4.

34. Kochva E, Bdolah A, Gram D, Wollberg Z. Sarafotoxins, a new group of cardiovascular modulators from snake venom. Mem Inst Butantan 1989;5i: 205-10.

35. Kochva E. Venomous snakes of Israel: ecology and snakebite. Public Health Rev. 1998;26:209-32.

36. Kourembanas S, Marsden PA, MC Quillan LP. Hypoxia induces endothelin gene expression and secretion in cultured human endothelium. J Clin Invest 1991;88:1054-7.

37. Kurnik D, Haviv Y, Kochva E. A snake bite by the burrowing asp, Atractaspis en gaddensis. Toxicon 1999;37:223-7.

38. Lange M, Pagotto U, Renner U, Arzberger T, Oeckler R, Stalla GK. The role of endothelins in the regulation of pituitary function. Exp Clin Endocrinol Diabetes 2002;110:103-12.

39. Lee SY, Lee CY, Chen YM, Kochva E. Coronary vasospasm as the primary cause of death due to the venom of the burrowing asp, Atractaspis engaddensis. Toxicon 1986;24:285-91.

40. Liu S, Premont RT, Kontos CD, Huang J, Rockey DC. Endothelin-1 activates endothelial cell nitric-oxide synthase via heterotrimeric G-protein betagamma subunit signaling to protein jinase B/Akt. J Biol Chem. 2003;278:49929-35.

41. Masuo Y, Ishikawa Y, Kozakai T, Uchide T, Komatsu Y, Saida K. Vasoactive in testinal contractor/endothelin-2 gene expression in the murine central nervous system. Biochem Biophys Res Commun 2003;300:661-8

42. Miller RC, Pelton JT, Huggins JP. Endothelins - from receptor to medicine Trends Pharmacol Sci 1993:14:54-60.

43. Oonuma H, Nakajima T, Nagata T, Iwasawa K, Wang Y, Hazama H, Morita Y Yamamoto K, Nagai R, Omata M. Endothelin-1 is a potent activator of nonselective cation currents in human bronchial smooth muscle cells. Am J Respir Cell Mol Biol 2000;23:213-21.

44. Patočka J, Měrka V. Bioregulators as agents of terrorism and warfare. Nederl Milit Geneesk T 2004;57:12-5.

45. Perreault T, Coceani F. Endothelin in the perinatal circulation. Can J Physiol Pharmacol 2003; 81:644-53.

46. Potaczek DP, Sanak M. Endothelin - biosynthesis, function and role in cardiovascular diseases (Article in Polish). Pol Arch Med Wewn 2002;108:703-14.

47. Randall MD, Donglas SA, Hiley CR. Vascular activities of" endothelin-1 and some alanyl substituted analogues in resistance beds of the rat. Br J Pharmaco 1989;98:685-99.

48. Rossi GP, Cavallin M, Nussdorfer GG, Pessina AC. The endothelin-aldosteron axis and cardiovascular diseases. J Cardiovasc Pharmacol 2001;38(Suppl 2):S49-52.
49. Sakurai T, Yanagisawa M, Takuwa Y. Cloning of a cDNA encoding a non - isopeptide selective subtype of the endothelin receptor. Nature 1990;348:732-5.

50. Savoia C, Schiffrin EL. Significance of recently identified peptides in hypertension: endothelin, natriuretic peptides, adrenomedullin, leptin. Med Clin North Am 2004;88:39-62.

51. Schiffrin EL. Endothelin -Potential role in hypertension and vascular hypertrophy. Hypertension 1995;25:1135-42.

52. Schinelli S.The brain endothelin system as potential target for brain-related pathologies. Curr Drug Target CNS Neurol Disord 2002;1:543-53

53. Sorensen SS, Madsen JK, Pedersen EB. Systemic and renal effect of intravenous infusion of endothelin-1 in healthy human volunteers. Am J Physio 1994;266:F411-8.

54. Spawls S, Branch B. The dangerous snakes of Africa. Sanibel Island, Florida: Ralph Curtis Publishing, Inc., 1995:389.

55. Takasaki C, Tamiya N, Bdolah A, Wollberg Z, Kochva E. Sarafotoxins S6: several isotoxins from Atractaspis engaddensis (burrowing asp) venom that affect the heart. Toxicon 1988:26:543-8.

56. Takuwa Y, Kasuya Y, Takuwa N. Endothelin receptor is coupled to phospholipase $\mathrm{C}$ via a pertusis toxin - insensitive guanine nucleotide - binding regulatory protein in vascular smooth muscle cells. J Clin Invest 1990;85:653-8.

57. Underwood G, Kochva E. On the affinities of the burrowing asps Atractaspis (Serpentes: Atractaspididae). Zool J Linn Soc 1993;107:3-64.

58. Vane JR, Anggand EA, Botting RM. Regulatory functions of the vascular endothelium. N Eng J Med 1990;323:27-36.

59. Vierhapper H, Wagner O, Nowotny P. Effect of endothelin-1 in man. Circulation 1991;81:1415-8.

60. Weiser E, Wollberg Z, Kochva E, Lee SY. Cardiotoxic effects of the venom of the burrowing asp, Atractaspis engaddensis (Atractaspididae, Ophidia). Toxicon 1984;22:767-74.

61. Wollberg Z, Shabo-Shina R, Intrator N, Bdolah A, Kochva E, Shavit G, Oron Y, Vidne BA, Gitter S. A novel cardiotoxic polypeptide from the venom of Atractaspis engaddensis (burrowing asp): cardiac effects in mice and isolated rat and human heart preparations. Toxicon 1988; 26:525-34.

62. Yanagisawa M, Kurihara $\mathrm{H}$, Kimura $\mathrm{S}$ et al. A novel potent vasoconstrictor peptide produced by vascular endothelial cells. Nature 1988;332:411-5.

Submitted April 2004

Accepted June 2004

Prof. RNDr. Jiří Patočka, DrSc., Purkyně Military Medical Academy,

Department of Toxicology, 50001 Hradec Králové, Czech Republic. e-mail: patocka@pmfhk.cz 